\title{
Review \\ Overview of Methods for Large-Scale RNA Synthesis
}

\author{
Marcin Ryczek, Martyna Pluta, Leszek Błaszczyk *(D) and Agnieszka Kiliszek *(D)
}

check for updates

Citation: Ryczek, M.; Pluta, M.; Błaszczyk, L.; Kiliszek, A. Overview of Methods for Large-Scale RNA Synthesis. Appl. Sci. 2022, 12, 1543. https://doi.org/10.3390/ app12031543

Academic Editor: Chih-Ching Huang

Received: 28 October 2021 Accepted: 28 January 2022 Published: 31 January 2022

Publisher's Note: MDPI stays neutral with regard to jurisdictional claims in published maps and institutional affiliations.

Copyright: (C) 2022 by the authors. Licensee MDPI, Basel, Switzerland. This article is an open access article distributed under the terms and conditions of the Creative Commons Attribution (CC BY) license (https:// creativecommons.org/licenses/by/ $4.0 /)$.

\author{
Institute of Bioorganic Chemistry, Polish Academy of Sciences, Noskowskiego 12/14, 61-704 Poznań, Poland; \\ mryczek@ibch.poznan.pl (M.R.); mpluta@ibch.poznan.pl (M.P.) \\ * Correspondence: blaszcz@ibch.poznan.pl (L.B.); kiliszek@ibch.poznan.pl (A.K.)
}

\begin{abstract}
In recent years, it has become clear that RNA molecules are involved in almost all vital cellular processes and pathogenesis of human disorders. The functional diversity of RNA comes from its structural richness. Although composed of only four nucleotides, RNA molecules present a plethora of secondary and tertiary structures critical for intra and intermolecular contacts with other RNAs and ligands (proteins, small metabolites, etc.). In order to fully understand RNA function it is necessary to define its spatial structure. Crystallography, nuclear magnetic resonance and cryogenic electron microscopy have demonstrated considerable success in determining the structures of biologically important RNA molecules. However, these powerful methods require large amounts of sample. Despite their limitations, chemical synthesis and in vitro transcription are usually employed to obtain milligram quantities of RNA for structural studies, delivering simple and effective methods for large-scale production of homogenous samples. The aim of this paper is to provide an overview of methods for large-scale RNA synthesis with emphasis on chemical synthesis and in vitro transcription. We also present our own results of testing the efficiency of these approaches in order to adapt the material acquisition strategy depending on the desired RNA construct.
\end{abstract}

Keywords: RNA; RNA crystallography; large-scale RNA synthesis; ribozymes

\section{Introduction}

Ribonucleic acid (RNA) is one of the major players involved in cell homeostasis [1]. Specific chemical features make RNA an important biological molecule, an interesting research object, and a tool adapted for human use [2,3]. In early nucleic acid research, there was no clear distinction between RNA and deoxyribonucleic acid (DNA); they were seen as "nuclein", a phosphor-rich substance different from proteins and present in large quantities in every living organism [4]. The pioneering work of many researchers, including Phoebus Levene, Albrech Kossel, and their co-workers, allowed to distinguish DNA and RNA molecules and to identify their basic components, such as ribose rings, nitrogen-containing bases, and phosphate groups [5-7]. Since then, RNA has been revealed as a multifaceted molecule that can form complex three-dimensional structures, presents catalytic properties, and serves as a regulatory element for governing gene expression [8-16]. On the other hand, RNA has also been identified as a toxic factor involved in the pathogenesis of numerous human disorders [17-19]. Finally, RNA became a tool applied in biotechnology and medicine [20-25]. The best-known examples are the mRNA-based vaccines used to fight the COVID-19 pandemic [26].

Knowledge of the three-dimensional structure of RNA is crucial for explaining its biological functions and conformational dynamics and for providing model platforms for drug development $[15,27,28]$. The pioneering studies on nucleic acid structure originated from research by Watson, Crick, and Franklin, who proposed the double-DNA-helix model [29,30]. The first atomic transfer RNA (tRNA) structure was determined by Robert Holley's group using single-crystal x-ray crystallography, opening up the field of structural studies of RNA molecules [31-33]. Subsequent discoveries of RNA properties (e.g., catalytic activity) and the development of methods for chemical and enzymatic synthesis increased 
interest in RNA and RNA-protein research, resulting in the three-dimensional structures of ribozymes, riboswitches, ribosomes, small nucleolar RNAs (snoRNAs), and other types of RNA being discovered [34-56]. These fundamental findings helped to explain the principles of RNA functions, folding pathways, the roles of water and ion molecules, and to reveal ligand-binding sites [57].

Structural studies of RNA molecules start with the design, synthesis, and purification of the macromolecule. In this step, the purity and homogeneity of the sample are critical for successful crystallization and diffraction experiments [58,59]. Another obstacle is the amount of material required for crystallization; milligrams of homogeneous RNA are usually needed [60-63]. Although a number of well-established protocols exist, obtaining a sufficient amount of pure RNA is challenging [60-63]. While chemical synthesis allows the production of large quantities of RNA, it is suitable only for relatively short RNA oligomers and requires a laboratory equipped with specific infrastructure (synthesizer, fume hood, vacuum evaporator, etc.). Moreover, modified phosphoramidites can be expensive and often non-commercially available. Longer RNAs can be effectively synthesized using in vitro transcription but this method suffers from considerable $3^{\prime}$-end heterogeneity and requires specific sequence requirements at the $5^{\prime}$-end. This paper provides an overview of large-scale RNA-synthesis methods used in structural studies, supplemented by our own results with the practical implementation of available protocols. In the first part, we describe methods for RNA synthesis and discuss their advantages and limitations. Next, we present the implementation of these methods and guidelines for adapting RNA-synthesis strategies.

\section{Methods of RNA Synthesis}

RNA can be obtained in three ways: purification from biological sources, chemical synthesis using a solid-phase method, or enzymatic synthesis by in vitro transcription. Isolation from cells is suitable for complex or large and highly abundant RNAs (ribosomes or tRNAs), resulting in native samples having all the important posttranscriptional modifications. Shorter or less-abundant RNAs can be synthesized chemically or enzymatically. These methods are more universal and preferred for structural studies of RNA molecules.

\subsection{Chemical Synthesis}

Solid-phase chemical synthesis using an automated synthesizer was established by Bruce Merrifield and was further applied for the synthesis of deoxyribonucleic and ribonucleic acids $[64,65]$. It is based on the cyclic elongation of the DNA/RNA chain on a solid support, e.g., controlled-pore glass or highly crosslinked polystyrene. It uses phosphoramidites decorated with different protection groups in order to block their reactivity during chemical synthesis [66]. There are several types of commercially available phosphoramidites. Most of them possess mild base-labile protection of exocyclic amino group of nucleobase and phosphate moiety blocked by 2 -cyanoethyl $N, N, N^{\prime}, N^{\prime}$-tetra-isopropyl [66]. In the case of 2'-hydroxyl, the most widely employed class of protection groups are TOM (triisopropylsilyl-oxy-methyl) and TBDMS (tert-butyldimethylsilyl). They are fluoridelabeled groups which are removed after synthesis using TBAF (tetra-n-butylammonium fluoride) or TEA.3HF (triethylamine trihydrofluoride). The $5^{\prime} \mathrm{OH}$ group is usually blocked by DMT (dimethoxytrityl) which is compatible with $2^{\prime} \mathrm{OH}$ silyl blockage [67]. The selection of the 2'-protection group is the most critical step affecting the yield and time of RNA synthesis. Recently, more potent activators such as ETT (5-ethylthio-1H-tetrazole) and BTT (5-benzylthio-1H-tetrazole) helped to increase the rate of the coupling step [68]. Other strategies of phosphoramidites protection have also been developed, resulting in shorter and higher efficiency of RNA synthesis. However, they are expensive, non-commercially available or require different protocols of solid-phase synthesis (for review see [66,69]). The standard solid-phase synthesis occurs from the $3^{\prime}$ to $5^{\prime}$-end, and one elongation cycle results in a chain extension by one nucleotide. Each cycle includes four steps: detritylation, coupling, capping, and oxidation (Figure 1) [66]. It starts with removing the dimethoxytrityl (DMT) protection group from the $5^{\prime} \mathrm{OH}$ group of the nucleotide attached to the solid 
support. This is followed by a coupling reaction, resulting in the chain elongation of oligomers with a $5^{\prime}$ DMT group originating from added phosphoramidite. Since the yield of coupling is less than $100 \%$, not all RNA chains are elongated. Thus, in the next step, the non-extended oligomers are $5^{\prime}$ capped, preventing their further extension in the next cycle. Finally, the phosphate group is oxidized and converted into a stable moiety $[62,66,70]$.

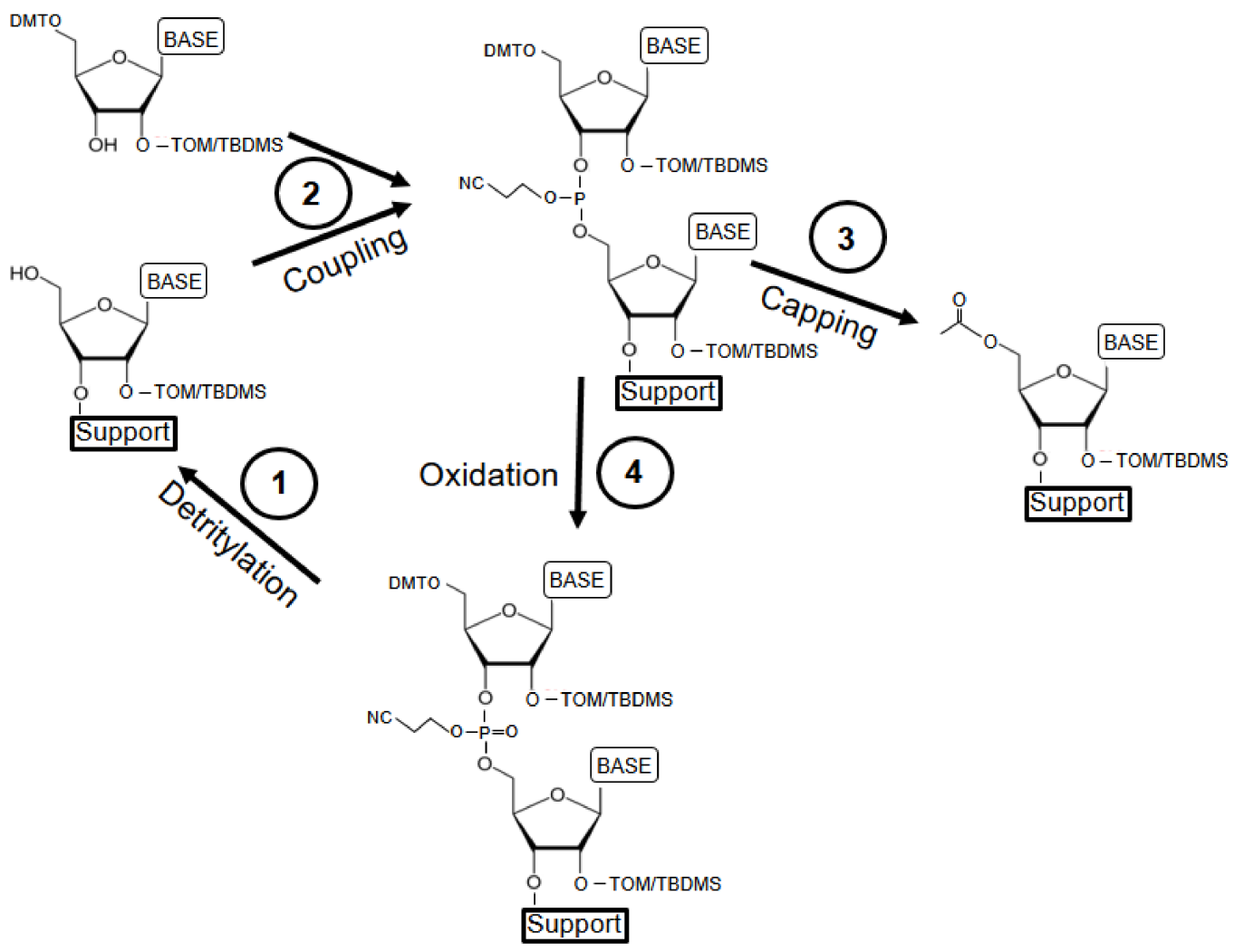

Figure 1. Overview of the solid-phase chemical RNA synthesis cycle.

Chemical synthesis is suitable for relatively short oligomers (up to $40 \mathrm{nt}-$ long). Although the yield of a single elongation cycle can reach $99 \%$, the overall efficiency drops systematically with each cycle. For 25 nt-long oligomers, the overall yield of synthesis is about $79 \%$, assuming an average single coupling efficiency of $99 \%$. When the coupling efficiency drops to $97 \%$, the overall yield is only approximately $48 \%$. For longer oligomers (50 nt), the overall yield is only $37 \%$, even if the average performance of a single coupling is $98 \%$ [71]. Therefore, chemical synthesis for longer RNAs is impractical, unless other reasons are considered, such as the introduction of modified nucleotides. In contrast to in vitro transcription, chemical modifications can be easily incorporated into RNA chains during automated synthesis. If the oligomer is too long to be efficiently synthesized, two shorter modified RNA chains can be obtained separately and ligated using split-join ligation or T4 RNA ligase [72-74]. The other advantage of chemical synthesis is fewer constraints on the sequence of RNA and lower heterogeneity in comparison to in vitro transcription.

In our laboratory, chemical synthesis is routinely used for the preparation of RNA oligomers. As an example, we have obtained 11 nt-long RNA oligomers using two approaches: DMT-OFF, in which the $5^{\prime}$ DMT group is removed from the last synthesized nucleotide, and DMT-ON, in which the $5^{\prime}$ DMT group is preserved and used for an additional purification step (Supplementary Materials). Both oligomers were cleaved from a solid support, and protective groups were removed according to standard procedures $[66,67]$. The DMT-ON oligomer was further purified using cartridges with an affinity for dimethoxy groups, while the DMT-OFF oligomer was only desalted. A comparison of the high-performance liquid chromatography (HPLC) chromatograms of samples showed high purity and homogeneity for DMT-ON RNA (compare Figure 2A,B). The DMT-OFF 
oligomer contained many short products, indicating the need for an additional purification step using thin-layer chromatography, polyacrylamide gel electrophoresis (PAGE), or HPLC. We also synthesized a 45 nt-long RNA oligomer (Figure 2C). Even though it was purified using the DMT-ON method, the amount of abortive products generated during the synthesis of longer RNA was very large, resulting in lower efficiency for the purification method.
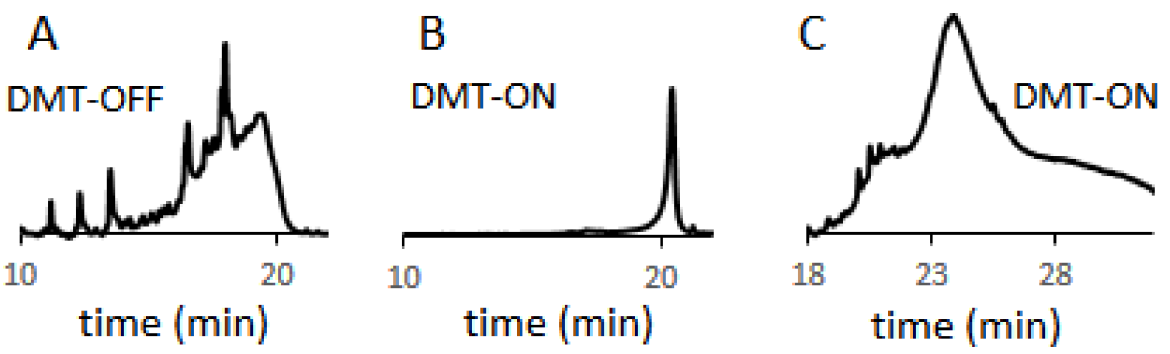

Figure 2. HPLC chromatograms of chemically synthesized RNAs: (A,B) 11 nt-long RNA oligomer synthesized in DMT-OFF and DMT-ON mode, respectively; (C) 45 nt-long RNA synthesized in DMT-ON mode.

In our hands, the average yield from $1 \mu \mathrm{mol}$-scale RNA synthesis resulted in at least $200 \mathrm{nmol}$ of pure oligomer of 8 to $22 \mathrm{nt}$. Short oligomers purified by the DMT-ON method were crystallized, and many of them resulted in crystals exhibiting a high diffraction potential (Figure 3 and data not shown). Longer RNAs were subjected to an additional purification step before crystallization.
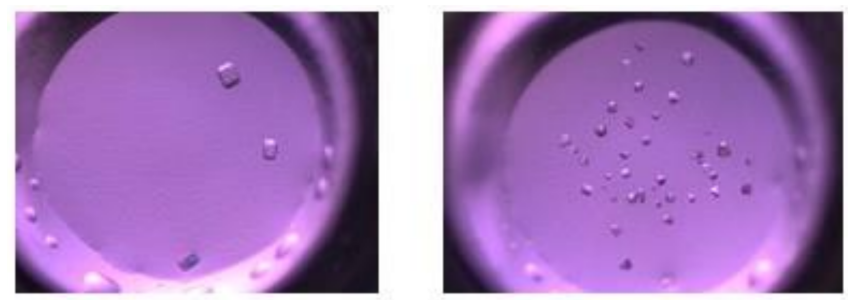

Figure 3. Examples of crystals that were grown from chemically synthesized RNAs.

\subsection{In Vitro RNA Synthesis Using T7 RNA Polymerase}

In vitro transcription is a common method used for synthesizing RNA molecules. It utilizes a DNA template with a promoter sequence for T7 RNA polymerase followed by a sequence encoding the target molecule [75]. The enzyme binds the template at the promoter region and starts the RNA synthesis. The elongation of the RNA chain terminates when the enzyme drops off the $3^{\prime}$-end of the DNA template [75]. In vitro synthesis can be efficient, resulting in milligrams of RNA sample, but a high yield depends on several factors. The most important is the type of nucleotides located immediately downstream of the $\mathrm{T} 7$ promoter. The transcript should start from at least one guanosine residue, but having two or three consecutive Gs is better [75-77]. Usually, the RNA sequence can be adjusted and mutations can be easily introduced into the DNA template. If the RNA sequence cannot be changed, catalytic RNAs can be employed (see below).

In structural studies, a serious drawback of in vitro RNA synthesis is the presence of short, abortive transcripts due to polymerase slippage and transcripts with additional nucleotides added to the $3^{\prime}$-end that are not encoded by the DNA template [78]. Separating short products from full-length oligomers is usually easy, while it is more difficult and time-consuming with transcripts extended by an additional one or two nucleotides [58]. The amounts of $\mathrm{N}+1$ and $\mathrm{N}+2$ products range from 10 to $50 \%$ of the whole synthesis, reducing the homogeneity, yield, and crystallization potential of the RNA sample [59].

In vitro transcription is conducted with a mixture of nucleoside triphosphates (NTPs), resulting in RNA having tri-phosphate at the $5^{\prime}$-end. In some instances, it can negatively 
influence the crystallization potential of the RNA by preventing the packing of RNA molecules into a crystal lattice or introducing disorder [79]. Thus, the conversion of the $5^{\prime}$ triphosphate into a $5^{\prime}$ hydroxyl group may be required to improve the crystallization and quality of the crystals. This can be easily performed by in vitro transcription in the presence of guanosine residues or with the use of alkaline phosphatase [59]. If a $5^{\prime}$ monophosphate group is required for further RNA modification, the transcription reaction can be supplemented with guanosine monophosphate (GMP).

In vitro transcription can be employed for the production of capped RNAs. Cap is a modified nucleotide (7-methylguanosine, $\mathrm{m}^{7} \mathrm{G}$ ) linked by the $5^{\prime}, 5^{\prime}$-triphosphate bond to the first transcribed nucleotide $[80,81]$. Cap structure increases the stability of cellular and exogenous mRNAs (such as vaccine mRNA) [82,83]. It is also required for mRNA splicing, export and initiation of translation $[82,84,85]$. Therefore, capped RNAs are widely used in studies concerning vital cellular processes [86-88]. The increasing demand on simple and efficient methods for synthesis of capped mRNAs resulted in the development of several protocols [86,89-91]. For long RNAs, cap structure is commonly introduced during in vitro transcription in the presence of chemically synthesized cap analogs such as $m^{7} G$, antireverse cap analog (ARCA) and its derivatives [86,90-94]. However, this method suffers from low efficiency which rarely exceeds $80 \%$ under optimized conditions. Moreover, it is limited to Cap 0 and the first transcribed nucleotide must be purine [95]. Recently, other capping reagents have been developed, extending the availability of different cap structures and increasing the yield of cap incorporation $[95,96]$. Short capped RNAs are synthesized using solid-phase synthesis but it requires non-standard phosphoramidites or modified solid supports [97-99].

\subsection{Ribozymes for RNA Production with Homogeneous Ends}

Ribozymes are self-cleaving RNAs found mainly in small-RNA pathogens of plants [100-102]. They are involved in the replication process, with a rolling-circle mechanism. As a result, long, linear concatamers of replicated genome of the pathogen are produced, which are cleaved by the catalytic domain of the ribozyme into unit-length progeny $[15,101,103]$. There are four types of small ribozyme motifs: hammerhead, hairpin, Varkud satellite (VS), and hepatitis delta virus (HDV) [104]. The glucosamine-6-phosphate riboswitch (GlmS) ribozyme is also classified as a small ribozyme, but in contrast to other catalytically active RNAs, it is activated by the binding of the ligand molecule [105]. All ribozymes catalyze the RNA-cleavage reaction, producing a $5^{\prime}$ hydroxyl group and $2^{\prime}, 3^{\prime}$-cyclic phosphate (Figure 4) [102]. For optimal activity, they require divalent metal ions such as $\mathrm{Mg}^{2+}$. Ribozymes usually act in cis mode when a substrate and ribozyme are present in single RNA chains, and cleavage separates RNA into two species (the catalytic domain of the ribozyme and target RNA). Ribozymes can also act in trans, recognizing a substrate by hybridizing to the complementary sequence and cleaving the RNA. Although ribozymes are commonly applied in different research areas, each type has its own specific requirements, mostly concerning the sequence of the RNA substrate (see below).
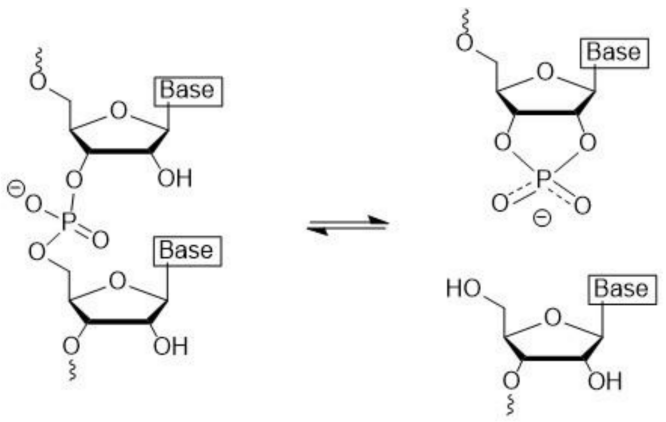

Figure 4. Ribozyme-mediated cleavage of RNA. 
Their relatively small size makes ribozymes attractive tools for use in structural studies for the production of RNA molecules with homogeneous ends or for enhancing the efficiency of in vitro transcription [61,63]. In the first case, they are incorporated into a DNA template upstream, downstream, or at both positions of the target sequence. During in vitro transcription, the RNA chain is cleaved, resulting in a mixture of target RNA and the catalytic domain of the ribozyme [61]. They need to be separated and purified using PAGE, gel filtration chromatography, or affinity tags [106,107].

When the ribozyme is located downstream of the target sequence, the $3^{\prime}$-end of the transcript RNA is homogeneous, but it possesses a $2^{\prime}, 3^{\prime}$-cyclic phosphate group (Figure 5A). The phosphate group can be removed with T4 polynucleotide kinase if the $3^{\prime} \mathrm{OH}$ group is required for downstream experiments [108]. The ribozyme is placed at the $5^{\prime}$-end of the target RNA to increase the yield of in vitro transcription or to produce RNA with homogeneous $5^{\prime}$-ends (Figure 5B). Higher efficiency in RNA synthesis is achieved by introducing the GGGAGA sequence at the beginning of the catalytic domain of the ribozyme, which ensures high processivity for the RNA polymerase [109]. This approach is also used when the sequence of the target RNA is critical and cannot be adjusted according to the T7 RNA polymerase's requirements. Since homogeneity and high yield in RNA synthesis are key factors for successful crystallization, one should consider RNA constructs with ribozymes at both ends (Figure 5C) [61]. Ribozymes can also be used in trans. This requires the co-transcription of the catalytic domain of the ribozyme and target RNA [110,111].

A

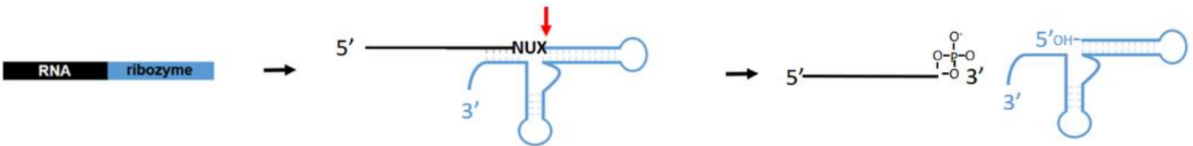

B
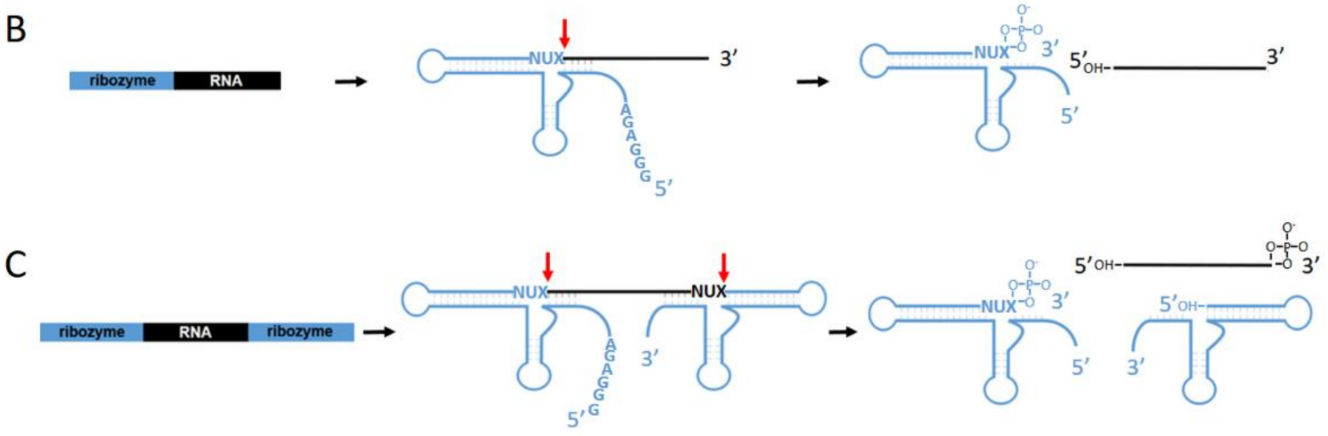

Figure 5. Production of homogeneous RNAs using ribozymes located at (A) $5^{\prime}-$ end, (B) $3^{\prime}$-end, and (C) both ends of the target RNA. Cleavage sites are indicated with red arrows.

\subsubsection{Hammerhead Ribozyme}

The hammerhead ribozyme is one of the most studied catalytic motifs found in viroids and satellite RNAs [112]. It is relatively small ( $40-50$ nucleotides), with a secondary structure consisting of three helices branching from the conserved junction region (Figure 6A). The length of the helical regions can be significantly altered without influencing ribozyme activity (one helix can be reduced to only two base pairs). The overall fold of the ribozyme resembles a Y-shape, and it is stabilized by loop-loop interactions [113,114]. A cleavage site is located at the $3^{\prime}$-end of the target RNA (next to helix I). It occurs after a NUX triplet ( $\mathrm{N}$ stands for any nucleotide, and $\mathrm{X}$ is any nucleotide except guanosine), and the optimal cleavage sequence is AUC, GUC, UUC $[110,115]$. Another important factor influencing the cleavage efficiency is the presence of divalent cations such as $\mathrm{Mg}^{2+}$ or $\mathrm{Mn}^{2+}$ at millimolar concentrations. They are involved in the proper folding of the ribozyme and serve as co-factors during the cleavage reaction [116]. 
A

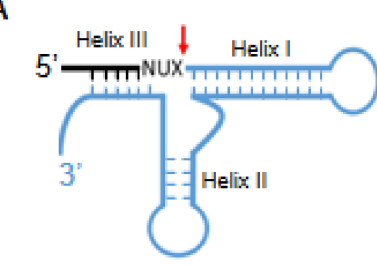

B

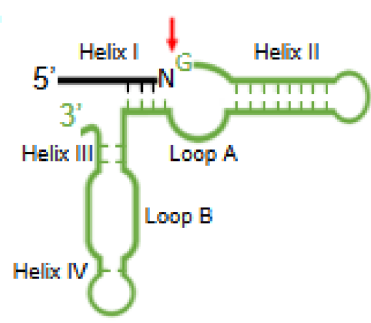

C

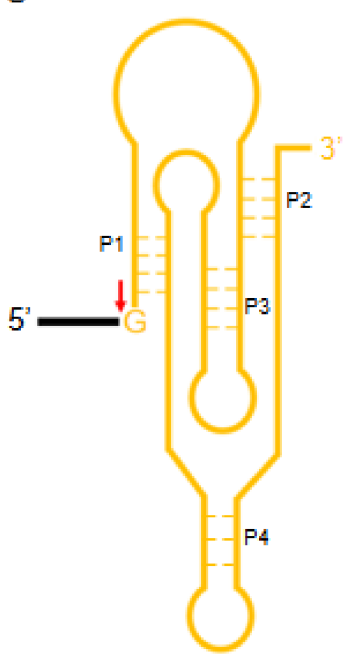

Figure 6. Secondary structure models of (A) hammerhead ribozyme, (B) hairpin ribozyme, and (C) HDV ribozyme. Target RNA is marked with black line. Cleavage sites are indicated with red arrows.

The hammerhead ribozyme has been widely used to generate RNA molecules with homogeneous ends. The efficient cleavage of RNAs ranging from 36 to $140 \mathrm{nt}$ has been observed for ribozymes located at either the $5^{\prime}$ or $3^{\prime}$-end, with optimum activity at a $24 \mathrm{mM}$ concentration of $\mathrm{Mg}^{2+}$ ions [61]. The hammerhead ribozyme has been successfully applied in crystallographic studies to synthesize part of the human 7SL RNA (Protein Data Bank-PDB: 1L9A), 4.5S rRNA domain IV (PDB: 1DUH), and tRNAIle (PDB: 6UFH) [117-119].

\subsubsection{Hairpin Ribozyme}

The hairpin ribozyme was identified in the minus strand of the tobacco ringspot virus satellite RNA (TRSV). It possesses four helical regions and two internal bulges (Figure 6B) [120]. The secondary structure of the hairpin ribozyme resembles the shape of a paperclip, but in three-dimensional space, the helices are coaxially arranged, representing two hairpin structures linked by a four-way junction [121]. Similar to the hammerhead ribozyme, helical regions of hairpin ribozyme can be engineered with different lengths and sequences without influencing the cleavage efficiency, as long as the integrity of the helices is maintained. The cleavage site is located in one of the conserved bulge regions. The optimal cleavage sequence is RYN $\downarrow$ GUC ( $R$ is a purine, $Y$ is a pyrimidine, and $N$ is any nucleotide) and occurs between N and G residues [100].

Due to different sequence constraints, the hairpin ribozyme has been proposed as an alternative to the hammerhead ribozyme. Although the cleavage efficiency has been observed to be high, the presence of the hairpin ribozyme leads to the generation of nonspecific products. This activity was shown to be reduced by a higher concentration (30 $\mathrm{mM})$ of $\mathrm{Mg}^{2+}$ ions [61].

\subsubsection{HDV-like Ribozymes}

An HDV ribozyme (approximately $85 \mathrm{nt}$ ) is found in the genomic and antigenomic strands of the hepatitis delta virus [122,123]. Its secondary structure consists of four helical regions forming two coaxial stacks, which are linked by two single-stranded junctions (Figure 6C). The tertiary structure of the HDV ribozyme folds into a nested double pseudoknot, constraining the overall shape and forming the active site of the ribozyme [123,124]. The cleavage site is located in helix P1 and typically occurs at a guanosine residue. The HDV ribozyme is active in the presence of divalent ions such as $\mathrm{Mg}^{2+}, \mathrm{Mn}^{2+}$, or $\mathrm{Ca}^{2+}$ [125]. The sequence upstream of the cleavage site is unrestricted. Therefore, the HDV ribozyme can be applied to generate $3^{\prime}$ homogeneous ends for any RNA. On the other hand, highly structured 
target RNAs can negatively influence the proper folding of the ribozyme domain, resulting in lower cleavage efficiency. In this case, incubating it at $65-70{ }^{\circ} \mathrm{C}$, adding urea, or performing cycles of denaturation-renaturation can enhance the cleavage efficiency [126-128].

The lack of a sequence requirement has resulted in the HDV ribozyme being widely used by structural researchers in the preparation of RNAs for crystallization. Examples include domain IV of the ribosomal 4.5S RNA from E. coli (PDB: 1DUH), the nadA riboswitch (PDB: 7D82), and the constitutive decay element (CDE1) from human $3^{\prime}$ untranslated region (PDB: 6XWW) [118,129,130].

\subsubsection{VS RNA Ribozyme}

The Varkud satellite RNA ribozyme was found in mitochondrial plasmids of certain strains of Neuropsora [104,131]. It is the longest known small ribozyme (150 nucleotides), but its sequence can be reduced to approximately $120 \mathrm{nt}$ without influencing its cleavage activity. The tertiary fold of the VS ribozyme is highly structured. It is composed of six double-stranded regions forming multihelix stacks, connected by three-way junctions and involving "kissing-loop" interactions [132]. Cleavage sites occur between A and G/A/U residues [133]. The VS ribozyme can act in cis and in trans, but only the trans system is suitable for the large-scale preparation of RNAs with homogeneous $3^{\prime}$-ends [110]. One of the examples is the preparation of the isotope-labelled RNA for NMR measurements [134].

\subsubsection{GlmS Ribozyme}

The GlmS ribozyme is a widespread, 145 nt-long, conserved element in Gram-positive bacteria located upstream of the glmS gene (encoding glutamine/fructose-6-phosphate aminotransferase) $[105,135]$. It was discovered as a riboswitch, but further characterization revealed that, instead of RNA protection, it induces RNA decay in the presence of metabolites. Thus, GlmS has been classified as a ribozyme activated by the binding of the ligand (glucosamine-6-phosphate, GlcN6P). The secondary structure of the GlmS ribozyme is composed of four double-stranded regions connected by four junctions, while its tertiary fold forms a compact structure with three near-parallel stacks comprising a total of three pseudoknots $[105,136]$. The cleavage site is located between conserved guanosine and adenosine residues, which are also involved in co-factor binding and the positioning of a scissile phosphate group [105]. GlmS has been successfully used for crystallographic studies of Xrn1-resistant RNAs (xrRNAs) from Flaviviridae (PDB: 4PQV) [137].

In order to test the efficiency of in vitro transcription using ribozymes, we designed and synthesized several constructs differing by location, type of ribozyme, and length and sequence of the target RNA (Table 1 and Supplementary Materials).

Table 1. RNA constructs used in this study.

\begin{tabular}{ccc}
\hline Construct & Ribozyme & Length of Target RNA \\
\hline RNA-HH 1 & $3^{\prime}$ hammerhead & $47 \mathrm{nt}$ \\
RNA-HH 2 & $3^{\prime}$ hammerhead & $30 \mathrm{nt}$ \\
RNA-HH 3 & $3^{\prime}$ hammerhead & $83 \mathrm{nt}$ \\
RNA-HH 4 & $3^{\prime}$ hammerhead & $86 \mathrm{nt}$ \\
RNA-HH 5 & $3^{\prime}$ hammerhead & $113 \mathrm{nt}$ \\
RNA-HH 6 & $3^{\prime}$ hammerhead & $43 \mathrm{nt}$ \\
HH-RNA-HH & $5^{\prime}$ hammerhead $/ 3^{\prime}$ hammerhead & $43 \mathrm{nt}$ \\
HH-RNA-HP & $5^{\prime}$ hammerhead/3' hairpin & $43 \mathrm{nt}$ \\
RNA-HDV 1 & $3^{\prime}$ HDV & $47 \mathrm{nt}$ \\
RNA-HDV 2 & $3^{\prime}$ HDV & $51 \mathrm{nt}$ \\
\hline
\end{tabular}

The RNA-HH 1 to 6 constructs possessed the hammerhead $(\mathrm{HH})$ ribozyme at the $3^{\prime}$-end and HH-RNA-HH hammerhead ribozyme at both ends. The HH-RNA-HP construct had the hammerhead ribozyme at the $5^{\prime}$ and hairpin (HP) ribozyme at the $3^{\prime}$-end, and RNA-HDV was equipped with the HDV-like ribozyme at the $3^{\prime}$-end. The constructs were prepared as chemically synthesized DNA or obtained by polymerase chain reaction (PCR). 
They were cloned into plasmid DNA, which was linearized prior to in vitro transcription. All the RNA-HH constructs showed a high cleavage efficiency independent of the sequence of the target RNA (Figure 7A-C). We estimated that more than $95 \%$ of the transcripts were cleaved. We added a $5^{\prime}$-end hammerhead ribozyme to the RNA-HH6 (a new construct, named $\mathrm{HH}-\mathrm{RNA}-\mathrm{HH}$ ) to increase the yield from in vitro transcription. Surprisingly, the efficiency of the cleavage was decreased to about 50\% (Figure 7C, line 2). We observed a band corresponding to an uncleaved intermediate RNA product attached to the $3^{\prime}$ hammerhead ribozyme. This suggests that the presence of the $5^{\prime}$ ribozyme affects the proper folding of $3^{\prime}$ hammerhead, reducing its cleavage activity.

A

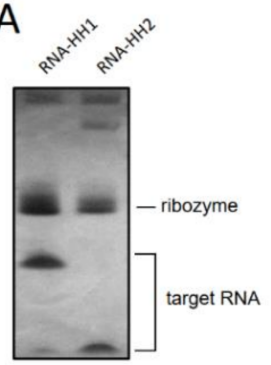

D

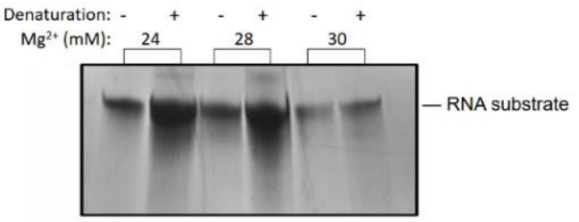

B

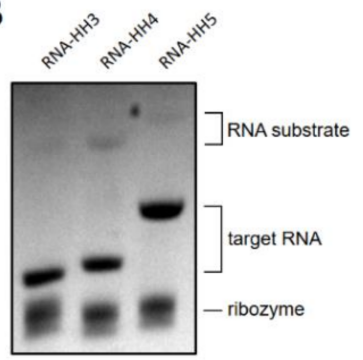

$\mathrm{E}$

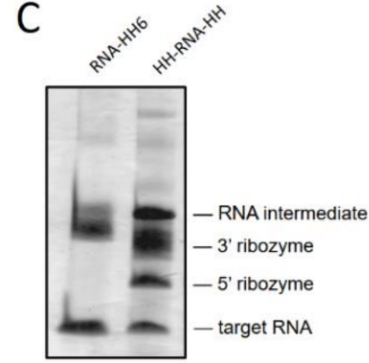

$\mathrm{F}$

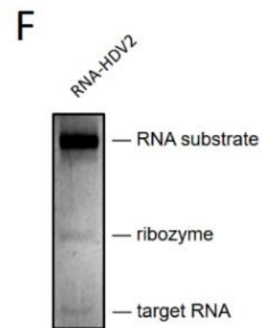

Figure 7. Assessment of ribozyme cleavage efficiency monitored by PAGE. (A-C) line 1, RNA-HH 1 to 6 constructs; (C) lane 2, construct HH-RNA-HH; (D) construct HH-RNA-HP (see text for details); (E) RNA-HDV 1 (see text for details); (F) RNA-HDV 2.

We replaced the $3^{\prime}$ hammerhead with the hairpin ribozyme in order to test whether other types of ribozymes at the $3^{\prime}$-end could increase the yield of the RNA product. However, this modification resulted in no cleavage of the HH-RNA-HP construct by either $5^{\prime}-$ or $3^{\prime}$-end-located ribozymes (Figure 7D, lane 1). Optimizing the reaction conditions by increasing the concentration of $\mathrm{Mg}^{2+}$ ions or performing cycles of denaturation-renaturation did not improve the cleavage efficiency (Figure 7D, lanes 2-6).

Finally, we tested the RNA-HDV 1 and 2 constructs with the HDV-like ribozyme at the $3^{\prime}$-end. Although we detected RNA products, the cleavage efficiency was very low (Figure 7E, lane 1, and Figure 7F). Incubating the sample at $65^{\circ} \mathrm{C}$ for $1 \mathrm{~h}$ after in vitro transcription (Figure 7E, lane 2), increasing the $\mathrm{Mg}^{2+}$ concentration (Figure 7E, lane 3), or incubating it in $4 \mathrm{M}$ urea (Figure 7E, lane 4) did not improve the cleavage efficiency, suggesting potential misfolding of the catalytic domain of the HDV ribozyme.

\subsection{Preparation of RNA with Homogeneous 3'-End Using Modified DNA Template}

The alternative method used for reducing RNA $3^{\prime}$-end heterogeneity is the modification of the DNA template for the in vitro transcription reaction. It requires incorporating one or two C2'-methoxy groups into the $5^{\prime}$-end of the antisense strand of the DNA template (Figure 8A) [78]. It was shown that C2'-methoxy modified DNA significantly reduced the $\mathrm{N}+1$ activity of RNA polymerase and increased the amount of proper RNA product compared to transcription carried out with an unmodified template $[78,138]$. Since the modifications are located on the sugar moiety, there is a low risk of incorporating nucleotides other than those encoded in the sequence. Such 2'-methoxy-modified phosphoramidites are commercially available. The DNA oligomer can be synthesized using an in-house 
synthesizer or purchased from external companies. For longer DNA templates, $2^{\prime}$-methoxy modifications can be incorporated during the PCR by using a $2^{\prime}$-methoxy-modified reverse primer $[78,138]$. Recent reports suggest that the reduction of the side products can be further improved by the addition of DMSO (dimethyl sulphoxide) $[139,140]$. This modification has been used for synthesis of $5^{\prime}$ leader of the HIV-1 genome for NMR studies [141].

A
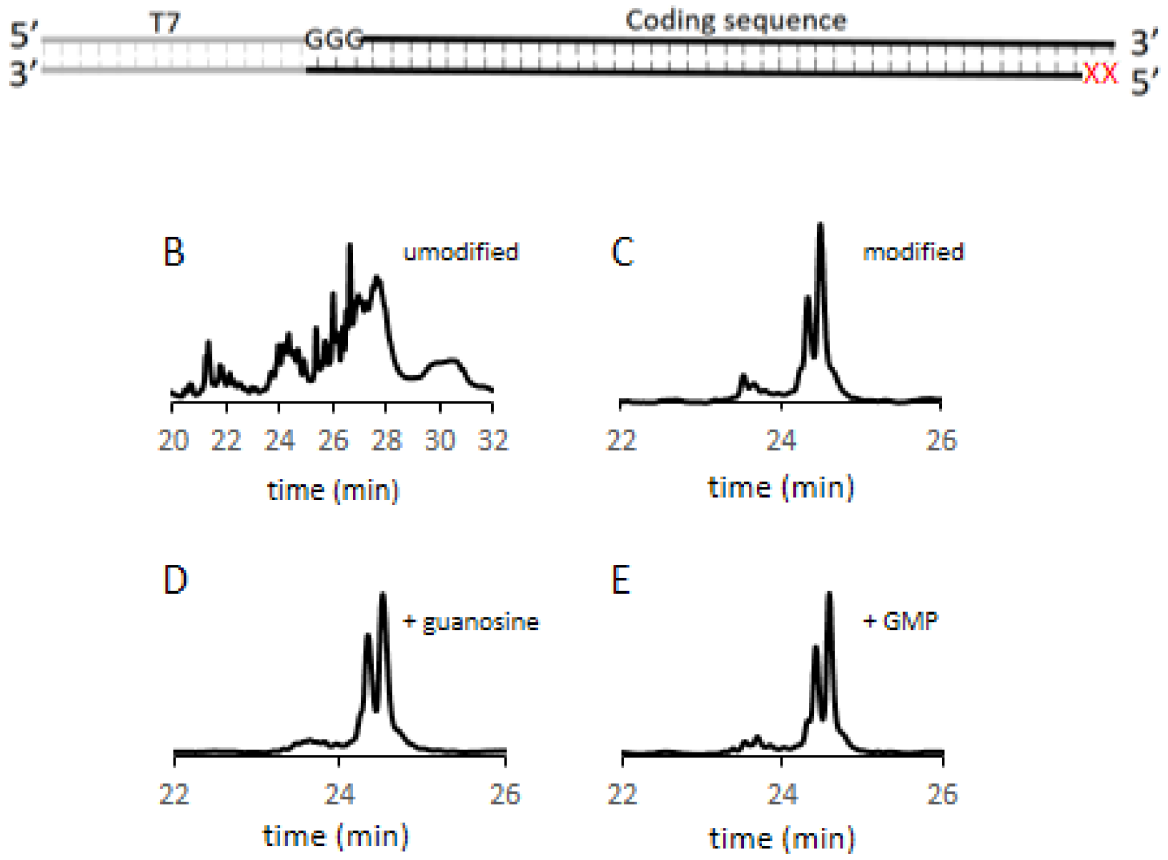

Figure 8. In vitro transcription of RNA using C2'-methoxy-modified DNA. (A) Schematic representation of DNA template. Modified nucleotides are marked with red Xs. Chromatograms showing RNA synthesis with (B) unmodified template, (C) C2'-methoxy-modified template, (D) C2' -methoxymodified template in the presence of $10 \mathrm{mM}$ guanosine, and (E) $\mathrm{C} 2^{\prime}$-methoxy-modified template in the presence of $15 \mathrm{mM}$ GTP.

We designed and synthesized a DNA template with two 2'-methoxy-modified nucleotides at the $5^{\prime}$-end of the antisense strand. Next, we performed in vitro transcription of modified and unmodified DNA templates in order to compare the homogeneity of the RNA products. HPLC analysis showed a significant reduction in RNA heterogeneity. With the modified DNA template, only two peaks were observed, and with the unmodified template, RNA products of different lengths were detected (Figure 8B,C).

Using the same method, we obtained RNAs with either a $5^{\prime} \mathrm{OH}$ or monophosphate group at the $5^{\prime}$-end by conducting in vitro transcription in the presence of guanosine or GMP, respectively. The HPLC analysis showed no difference in chromatograms compared to the control transcription reactions (Figure 8D,E). The presence of a monophosphate at the $5^{\prime}$-end was further confirmed by the ligation reaction (data not shown).

\section{Discussion}

This paper provides an overview of methods for large-scale RNA synthesis. We also describe our experience during the preparation of homogeneous samples for crystallization experiments (summarized in Table 2). Many factors should be taken into account when selecting methods for the production of milligram quantities of RNA suitable for structural studies. They include the length of the oligomer, the presence of specific chemical modifications, the oligomer manufacturing time, cost, and equipment availability. 
Table 2. Factors that should be considered for the efficient chemical and enzymatic synthesis of RNA.

\begin{tabular}{|c|c|}
\hline Method & Important Factors \\
\hline Chemical synthesis & $\begin{array}{ll}\text { - } & \text { Higly efficient for short oligomers (up to } 20 \mathrm{nt} \text { ) } \\
\text { - } & \text { High-grade phosphoramidites (preferably TOM protection) } \\
\text { - } & \text { Acetonitryl with lowest possible content of water (up to } 20 \mathrm{ppm} \text { ) } \\
\text { - } & \text { Preferable synthesis in DMT-ON mode }\end{array}$ \\
\hline In vitro transcription & $\begin{array}{l}\text { - Concentration of DNA template }(50-100 \mu \mathrm{g} / \mathrm{mL}) \text { and reaction } \\
\text { time }(12-16 \mathrm{~h}) \\
\text { - } \quad \text { Hammerhead ribozyme showed highest cleavage efficiency } \\
\text { DNA template with } \mathrm{C} 2^{\prime} \text {-methoxy modifications reduces } \\
3^{\prime} \text {-end heterogeneity }\end{array}$ \\
\hline
\end{tabular}

From our experience, chemical synthesis allows the preparation of sufficient quantities of RNA up to 20 nucleotides. Longer ( $>40 \mathrm{nt}$ ) oligomers can be synthesized but with much lower efficiency. Chemically synthesized RNA can also be purchased from external companies. However, since crystallization experiments often require testing large numbers of different constructs, using in-house synthesizers significantly reduces the cost of RNA production. We observed that in order to obtain a high yield of chemically synthesized RNA, it is crucial to dissolve reagents in acetonitrile with the lowest possible water content (up to $20 \mathrm{ppm}$ ). We recommend TOM rather than TBDMS protected phosphoramidites. They are characterized by higher coupling efficiency due to lower steric hindrance and prevented relocation from $2^{\prime}$ to $3^{\prime}$ moiety of ribose ring. The $2^{\prime}$ to $3^{\prime}$ migration can take place when using the TBDMS group, leading to the formation of non-biologically active $2^{\prime}-5^{\prime}$ linkages. The costs of TOM and TBDMS phosphoramidites are comparable. When modified phosphoramidites are produced in-house they should have the highest possible purity, because some $\mathrm{H}$-phosphonate or other impurities can still be present, reducing the coupling efficiency. RNA oligomers should be synthesized with the DMT-ON method, which significantly increases the homogeneity of the sample. DMT-ON purification on dedicated columns can remove abortive products, and the resulting RNA is suitable for crystallization or nuclear magnetic resonance measurements (Figure 2). With longer oligomers, additional purification steps are usually required to obtain homogeneous RNA.

In vitro transcription is suitable for longer RNA, but its main drawback is the nonspecific activity of the RNA polymerase generating $3^{\prime}$-end heterogeneity. Homogeneous samples can be achieved by using ribozymes cleaving at the $3^{\prime}$ site of the RNA construct. In our hands, the hammerhead ribozyme was characterized by the highest $(\sim 90 \%)$ cleavage efficiency, while the HDV-like ribozyme cleaved RNA less efficiently (Figure 7). Despite the careful design of RNA constructs to fulfill all the requirements for the proper folding of the catalytic domains of ribozymes, the cleavage efficiency was low when ribozymes were present at both ends of the RNA. An extreme example is the HP-RNA-HH construct, where the replacement of the $5^{\prime}$ hammerhead with the hairpin ribozyme led to the complete inhibition of cleavage (Figure 7). The presence of the $5^{\prime}$ hairpin ribozyme could interfere with the folding of the $3^{\prime}$ hammerhead ribozyme. As a result, both ribozymes became inactive. The ribozyme approach requires the purification of the RNA product from uncleaved RNA and the catalytic domain of the ribozyme. Therefore, the lengths of the ribozyme and the RNA of interest should differ in such a way that they can be separated with gel electrophoresis or HPLC. An attractive alternative to the ribozyme approach is in vitro transcription of the C2'-methoxy-modified DNA. This does not have specific requirements for the proper folding of catalytic RNAs, and a DNA template can be obtained from external companies or synthesized in-house. Using this method, we observed significant improvement in terms of the RNA's $3^{\prime}$-end homogeneity (Figure 8 ). Although N+1 activity of RNA polymerase was still present, RNAs were easily separated using HPLC or gel electrophoresis (data not shown). 
Concerning factors influencing the yield of RNA transcription, we noted that the most important were DNA template concentration $(50-100 \mu \mathrm{g} / \mathrm{mL})$ and reaction incubation time (12-16 h). Although the adjusting concentration of magnesium ions and ribonucleotides often improves the yield of transcription, we did not observe significant differences in the amount of synthesized RNA (data not shown) [142].

\section{Conclusions}

RNA is involved in the regulation of almost all aspects of cell physiology. Structural richness of RNA molecules has been explored, not only by nature but also adapted by humans in the construction of tools for molecular biology, biomedicine and nanotechnology. Therefore, investigation of RNA three-dimensional structures is fundamentally important and is a key to understanding the RNA-function relationship.

Here, we reviewed well-established methods for large-scale production of homogenous RNA with emphasis on chemical synthesis and in vitro transcription. We also present the results of the incorporation of these methods to obtain RNA suitable for crystallographic experiments. Although preparation of such RNA is still a serious bottleneck, chemical synthesis and in vitro transcription provide simple and effective ways of sample production.

In recent years, a number of new methods for large-scale RNA synthesis have emerged, such as circular RNAs, and position-selective labeling of RNA and polymerase chain transcription (for review see [62,143]). Although still under development, they show new research avenues with great potential to open up the field of structural studies of RNA.

We anticipate that this paper will be useful for many researchers. It will help in choosing a method for large-scale RNA production depending on the chemical nature of the target molecule and avoiding difficulties during sample preparation.

Supplementary Materials: The following are available online at https:/ / www.mdpi.com/article/ 10.3390/app12031543/s1, Materials and Methods (DNA / RNA synthesis and purification, in vitro transcription and HPLC analysis).

Author Contributions: Conceptualization, M.R., A.K. and L.B.; methodology, M.R., M.P., L.B. and A.K.; investigation, M.R, M.P. and L.B.; writing-original draft preparation, M.R, L.B and A.K.; writing-review and editing, A.K and L.B.; visualization, M.R.; supervision, A.K.; project administration, A.K.; funding acquisition, A.K. All authors have read and agreed to the published version of the manuscript.

Funding: This research was funded by the National Science Centre, Poland, grant number UMO2017/26/E/NZ1/00950.

Institutional Review Board Statement: Not applicable.

Informed Consent Statement: Not applicable.

Conflicts of Interest: The authors declare no conflict of interest. The funders had no role in the design of the study; in the collection, analyses, or interpretation of data; in the writing of the manuscript, or in the decision to publish the results.

\section{References}

1. Sharp, P.A. The Centrality of RNA. Cell 2009, 136, 577-580. [CrossRef] [PubMed]

2. Michelini, F.; Jalihal, A.P.; Francia, S.; Meers, C.; Neeb, Z.T.; Rossiello, F.; Gioia, U.; Aguado, J.; Jones-Weinert, C.; Luke, B.; et al. From "Cellular" RNA to "Smart" RNA: Multiple Roles of RNA in Genome Stability and Beyond. Chem. Rev. 2018, 118, $4365-4403$. [CrossRef] [PubMed]

3. Strobel, E.J.; Watters, K.E.; Loughrey, D.; Lucks, J.B. RNA systems biology: Uniting functional discoveries and structural tools to understand global roles of RNAs. Curr. Opin. Biotechnol. 2016, 39, 182-191. [CrossRef]

4. Frixione, E.; Ruiz-Zamarripa, L. The "scientific catastrophe" in nucleic acids research that boosted molecular biology. J. Biol. Chem. 2019, 294, 2249-2255. [CrossRef] [PubMed]

5. Levene, P.A.; Tipson, R.S. The ring structure of thymidine. Science 1935, 81, 98. [CrossRef]

6. Levene, P.A. On the biochemistry of nucleic acids. J. Am. Chem. Soc. 1910, 32, 231-240. [CrossRef]

7. Kossel, A.; Neumann, A. Ueber das Thymin, ein Spaltungsproduct der Nucleïnsäure. Berichte Dtsch. Chem. Gesellschaft 1893, 26, 2753-2756. [CrossRef] 
8. Jones, C.P.; Ferré-D'Amaré, A.R. Long-Range Interactions in Riboswitch Control of Gene Expression. Annu. Rev. Biophys. 2017, 46, 455-481. [CrossRef]

9. Winkler, W.; Nahvi, A.; Breaker, R.R. Thiamine derivatives bind messenger RNAs directly to regulate bacterial gene expression. Nature 2002, 419, 952-956. [CrossRef]

10. Kruger, K.; Grabowski, P.J.; Zaug, A.J.; Sands, J.; Gottschling, D.E.; Cech, T.R. Self-splicing RNA: Autoexcision and autocyclization of the ribosomal RNA intervening sequence of tetrahymena. Cell 1982, 31, 147-157. [CrossRef]

11. Guerrier-Takada, C.; Gardiner, K.; Marsh, T.; Pace, N.; Altman, S. The RNA moiety of ribonuclease P is the catalytic subunit of the enzyme. Cell 1983, 35, 849-857. [CrossRef]

12. Statello, L.; Guo, C.-J.; Chen, L.-L.; Huarte, M. Gene regulation by long non-coding RNAs and its biological functions. Nat. Rev. Mol. Cell Biol. 2021, 22, 96-118. [CrossRef] [PubMed]

13. Hendrix, D.K.; Brenner, S.E.; Holbrook, S.R. RNA structural motifs: Building blocks of a modular biomolecule. Q. Rev. Biophys. 2005, 38, 221-243. [CrossRef] [PubMed]

14. Leontis, N.B.; Lescoute, A.; Westhof, E. The building blocks and motifs of RNA architecture. Curr. Opin. Struct. Biol. 2006, 16, 279-287. [CrossRef]

15. Serganov, A.; Patel, D.J. Ribozymes, riboswitches and beyond: Regulation of gene expression without proteins. Nat. Rev. Genet. 2007, 8, 776-790. [CrossRef] [PubMed]

16. Stavast, C.; Erkeland, S. The Non-Canonical Aspects of MicroRNAs: Many Roads to Gene Regulation. Cells $2019,8,1465$. [CrossRef]

17. Malik, I.; Kelley, C.P.; Wang, E.T.; Todd, P.K. Molecular mechanisms underlying nucleotide repeat expansion disorders. Nat. Rev. Mol. Cell Biol. 2021, 22, 589-607. [CrossRef] [PubMed]

18. Esteller, M. Non-coding RNAs in human disease. Nat. Rev. Genet. 2011, 12, 861-874. [CrossRef] [PubMed]

19. Zhang, Y.-Z.; Wu, W.-C.; Shi, M.; Holmes, E.C. The diversity, evolution and origins of vertebrate RNA viruses. Curr. Opin. Virol. 2018, 31, 9-16. [CrossRef]

20. Lundstrom, K. RNA Viruses as Tools in Gene Therapy and Vaccine Development. Genes 2019, 10, 189. [CrossRef]

21. Schmidt, C.M.; Smolke, C.D. RNA Switches for Synthetic Biology. Cold Spring Harb. Perspect. Biol. 2019, 11, a032532. [CrossRef] [PubMed]

22. Ouellet, J. RNA Fluorescence with Light-Up Aptamers. Front. Chem. 2016, 4, 1-12. [CrossRef] [PubMed]

23. Pfeiffer, F.; Mayer, G. Selection and Biosensor Application of Aptamers for Small Molecules. Front. Chem. 2016, 4, 25. [CrossRef]

24. Guo, P. The emerging field of RNA nanotechnology. Nat. Nanotechnol. 2010, 5, 833-842. [CrossRef]

25. Bennett, C.F.; Krainer, A.R.; Cleveland, D.W. Antisense Oligonucleotide Therapies for Neurodegenerative Diseases. Annu. Rev. Neurosci. 2019, 42, 385-406. [CrossRef]

26. Meo, S.A.; Bukhari, I.A.; Akram, J.; Meo, A.S.; Klonoff, D.C. COVID-19 vaccines: Comparison of biological, pharmacological characteristics and adverse effects of pfizer/BioNTech and moderna vaccines. Eur. Rev. Med. Pharmacol. Sci. 2021, 25, 1663-1679. [CrossRef] [PubMed]

27. Warner, K.D.; Hajdin, C.E.; Weeks, K.M. Principles for targeting RNA with drug-like small molecules. Nat. Rev. Drug Discov. 2018, 17, 547-558. [CrossRef] [PubMed]

28. Hermann, T. Small molecules targeting viral RNA. Wiley Interdiscip. Rev. RNA 2016, 7, 726-743. [CrossRef] [PubMed]

29. Watson, J.D.; Crick, F.H.C. Molecular Structure of Nucleic Acids: A Structure for Deoxyribose Nucleic Acid. Nature 1953, 171, 737-738. [CrossRef] [PubMed]

30. Franklin, R.E.; Gosling, R.G. Molecular Configuration in Sodium Thymonucleate. Nature 1953, 171, 740-741. [CrossRef] [PubMed]

31. Clark, B.F.C. The crystal structure of tRNA. J. Biosci. 2006, 31, 453-457. [CrossRef] [PubMed]

32. Holley, R.W.; Apgar, J.; Everett, G.A.; Madison, J.T.; Marquisee, M.; Merrill, S.H.; Penswick, J.R.; Zamir, A. Structure of a ribonucleic acid. Science 1965, 147, 1462-1465. [CrossRef] [PubMed]

33. Rich, A. The Era of RNA Awakening: Structural biology of RNA in the early years. Q. Rev. Biophys. 2009, 42, 117-137. [CrossRef] [PubMed]

34. Pley, H.W.; Flaherty, K.M.; McKay, D.B. Three-dimensional structure of a hammerhead ribozyme. Nature 1994, 372, 68-74. [CrossRef] [PubMed]

35. Ren, A.; Micura, R.; Patel, D.J. Structure-based mechanistic insights into catalysis by small self-cleaving ribozymes. Curr. Opin. Chem. Biol. 2017, 41, 71-83. [CrossRef]

36. Klein, D.J.; Edwards, T.E.; Ferré-D'Amaré, A.R. Cocrystal structure of a class I preQ1 riboswitch reveals a pseudoknot recognizing an essential hypermodified nucleobase. Nat. Struct. Mol. Biol. 2009, 16, 343-344. [CrossRef]

37. Cate, J.H.; Yusupov, M.M.; Yusupova, G.Z.; Earnest, T.N.; Noller, H.F. X-ray crystal structures of $70 S$ ribosome functional complexes. Science 1999, 285, 2095-2104. [CrossRef]

38. Wimberly, B.T.; Brodersen, D.E.; Clemons, W.M.; Morgan-Warren, R.J.; Carter, A.P.; Vonrhein, C.; Hartsch, T.; Ramakrishnan, V. Structure of the $30 \mathrm{~S}$ ribosomal subunit. Nature 2000, 407, 327-339. [CrossRef]

39. Ban, N.; Nissen, P.; Hansen, J.; Moore, P.B.; Steitz, T.A. The complete atomic structure of the large ribosomal subunit at $2.4 \AA$ resolution. Science 2000, 289, 905-920. [CrossRef]

40. Schluenzen, F.; Tocilj, A.; Zarivach, R.; Harms, J.; Gluehmann, M.; Janell, D.; Bashan, A.; Bartels, H.; Agmon, I.; Franceschi, F.; et al. Structure of Functionally Activated Small Ribosomal Subunit at 3.3 Å Resolution. Cell 2000, 102, 615-623. [CrossRef] 
41. Yusupov, M.M.; Yusupova, G.Z.; Baucom, A.; Lieberman, K.; Earnest, T.N.; Cate, J.H.D.; Noller, H.F. Crystal structure of the ribosome at $5.5 \AA$ A resolution. Science 2001, 292, 883-896. [CrossRef] [PubMed]

42. Oubridge, C.; Ito, N.; Evans, P.R.; Teo, C.H.; Nagai, K. Crystal structure at $1.92 \AA$ resolution of the RNA-binding domain of the U1A spliceosomal protein complexed with an RNA hairpin. Nature 1994, 372, 432-438. [CrossRef] [PubMed]

43. Allain, F.H.T.; Howe, P.W.A.; Neuhaus, D.; Varani, G. Structural basis of the RNA-binding specificity of human U1A protein. EMBO J. 1997, 16, 5764-5774. [CrossRef] [PubMed]

44. Bonilla, S.L.; Sherlock, M.E.; MacFadden, A.; Kieft, J.S. A viral RNA hijacks host machinery using dynamic conformational changes of a tRNA-like structure. Science 2021, 374, 955-960. [CrossRef] [PubMed]

45. Akiyama, B.M.; Laurence, H.M.; Massey, A.R.; Costantino, D.A.; Xie, X.; Yang, Y.; Shi, P.Y.; Nix, J.C.; Beckham, J.D.; Kieft, J.S. Zika virus produces noncoding RNAs using a multi-pseudoknot structure that confounds a cellular exonuclease. Science 2016, 354, 1148-1152. [CrossRef] [PubMed]

46. Cate, J.H.; Gooding, A.R.; Podell, E.; Zhou, K.; Golden, B.L.; Kundrot, C.E.; Cech, T.R.; Doudna, J.A. Crystal structure of a group I ribozyme domain: Principles of RNA packing. Science 1996, 273, 1678-1685. [CrossRef]

47. Imai, S.; Kumar, P.; Hellen, C.U.T.; D'Souza, V.M.; Wagner, G. An accurately preorganized IRES RNA structure enables eIF4G capture for initiation of viral translation. Nat. Struct. Mol. Biol. 2016, 23, 859-864. [CrossRef]

48. Brown, J.A.; Bulkley, D.; Wang, J.; Valenstein, M.L.; Yario, T.A.; Steitz, T.A.; Steitz, J.A. Structural insights into the stabilization of MALAT1 noncoding RNA by a bipartite triple helix. Nat. Struct. Mol. Biol. 2014, 21, 633-640. [CrossRef] [PubMed]

49. Błaszczyk, L.; Rypniewski, W.; Kiliszek, A. Structures of RNA repeats associated with neurological diseases. Wiley Interdiscip. Rev. RNA 2017, 8, e1412. [CrossRef]

50. Ferré-D'Amaré, A.R.; Zhou, K.; Doudna, J.A. Crystal structure of a hepatitis delta virus ribozyme. Nature 1998, 395, 567-574 [CrossRef]

51. Golden, B.L.; Gooding, A.R.; Podell, E.R.; Cech, T.R. A preorganized active site in the crystal structure of the Tetrahymena ribozyme. Science 1998, 282, 259-264. [CrossRef] [PubMed]

52. Serganov, A.; Yuan, Y.R.; Pikovskaya, O.; Polonskaia, A.; Malinina, L.; Phan, A.T.; Hobartner, C.; Micura, R.; Breaker, R.R.; Patel, D.J. Structural basis for discriminative regulation of gene expression by adenine- and guanine-sensing mRNAs. Chem. Biol. 2004, 11, 1729-1741. [CrossRef] [PubMed]

53. Thore, S.; Leibundgut, M.; Ban, N. Structure of the Eukaryotic Thiamine Pyrophosphate Riboswitch with Its Regulatory Ligand. Science 2006, 312, 1208-1211. [CrossRef] [PubMed]

54. Serganov, A.; Polonskaia, A.; Phan, A.T.; Breaker, R.R.; Patel, D.J. Structural basis for gene regulation by a thiamine pyrophosphatesensing riboswitch. Nature 2006, 441, 1167-1171. [CrossRef] [PubMed]

55. Roth, A.; Breaker, R.R. The Structural and Functional Diversity of Metabolite-Binding Riboswitches. Annu. Rev. Biochem. 2009, 78, 305-334. [CrossRef]

56. Duchardt-Ferner, E.; Gottstein-Schmidtke, S.R.; Weigand, J.E.; Ohlenschläger, O.; Wurm, J.P.; Hammann, C.; Suess, B.; Wöhnert, J. What a Difference an $\mathrm{OH}$ Makes: Conformational Dynamics as the Basis for the Ligand Specificity of the Neomycin-Sensing Riboswitch. Angew. Chem. Int. Ed. 2016, 55, 1527-1530. [CrossRef] [PubMed]

57. Westhof, E. Twenty years of RNA crystallography. RNA 2015, 21, 486-487. [CrossRef] [PubMed]

58. Holbrook*, S.R.; Holbrook, E.L.; Walukiewicz, H.E. Crystallization of RNA. Cell. Mol. Life Sci. 2001, 58, 234-243. [CrossRef] [PubMed]

59. Golden, B.L.; Kundrot, C.E. RNA crystallization. J. Struct. Biol. 2003, 142, 98-107. [CrossRef]

60. Ferré-D'Amaré, A.R.; Doudna, J.A. Methods to Crystallize RNA. Curr. Protoc. Nucleic Acid Chem. 2000, 1, 1-13. [CrossRef]

61. Price, S.R.; Ito, N.; Oubridge, C.; Avis, J.M.; Nagai, K. Crystallization of RNA-protein complexes I. Methods for the large-scale preparation of RNA suitable for crystallographic studies. J. Mol. Biol. 1995, 249, 398-408. [CrossRef] [PubMed]

62. Baronti, L.; Karlsson, H.; Marušič, M.; Petzold, K. A guide to large-scale RNA sample preparation. Anal. Bioanal. Chem. 2018, 410, 3239-3252. [CrossRef] [PubMed]

63. Ahmed, Y.L.; Ficner, R. RNA synthesis and purification for structural studies. RNA Biol. 2014, 11, 427-432. [CrossRef] [PubMed]

64. Merrifield, R.B. Solid Phase Peptide Synthesis. I. The Synthesis of a Tetrapeptide. J. Am. Chem. Soc. 1963, 85, 2149-2154. [CrossRef]

65. Josephson, S.; Lagerholm, E.; Palm, G.; Mörch, L.; Norin, T. Automatic Synthesis of Oligodeoxynucleotides and Mixed Oligodeoxynucleotides using the Phosphoamidite Method. Acta Chem. Scand. 1984, 38, 539-545. [CrossRef] [PubMed]

66. Flamme, M.; McKenzie, L.K.; Sarac, I.; Hollenstein, M. Chemical methods for the modification of RNA. Methods 2019, 161, 64-82. [CrossRef]

67. Bartosik, K.; Debiec, K.; Czarnecka, A.; Sochacka, E.; Leszczynska, G. Synthesis of Nucleobase-Modified RNA Oligonucleotides by Post-Synthetic Approach. Molecules 2020, 25, 3344. [CrossRef]

68. Somoza, Á. Protecting groups for RNA synthesis: An increasing need for selective preparative methods. Chem. Soc. Rev. 2008, 37, 2668. [CrossRef]

69. Beaucage, S.L.; Reese, C.B. Recent Advances in the Chemical Synthesis of RNA. Curr. Protoc. Nucleic Acid Chem. 2009, 38, 1-31. [CrossRef]

70. Sekine, M. Recent development of chemical synthesis of RNA. In Synthesis of Therapeutic Oligonucleotides; Springer: Berlin/Heidelberg, Germany, 2018; pp. 41-65, ISBN 9789811319129.

71. Reese, C.B. Oligo- and poly-nucleotides: 50 years of chemical synthesis. Org. Biomol. Chem. 2005, 3, 3851-3868. [CrossRef] 
72. Moore, M.; Charles, Q. Use of site-specifically modified RNAs constructed by RNA ligation. In RNA: Protein Interactions. A Practical Approach; Smith, C., Ed.; Oxford University Press: Oxford, UK, 1998; pp. 75-108, ISBN 0-19-963651-6.

73. Höbartner, C.; Micura, R. Chemical Synthesis of Selenium-Modified Oligoribonucleotides and Their Enzymatic Ligation Leading to an U6 SnRNA Stem-Loop Segment. J. Am. Chem. Soc. 2004, 126, 1141-1149. [CrossRef] [PubMed]

74. Kiliszek, A.; Błaszczyk, L.; Kierzek, R.; Rypniewski, W. Stabilization of RNA hairpins using non-nucleotide linkers and circularization. Nucleic Acids Res. 2017, 45, e92. [CrossRef]

75. Beckert, B.; Masquida, B. Synthesis of RNA by In Vitro Transcription. In RNA. Methods in Molecular Biology (Methods and Protocols); Nielsen, H., Ed.; Humana Press: Totowa, NJ, USA, 2011; Volume 703, ISBN 978-1-58829-913-0.

76. Coleman, T.M.; Wang, G.; Huang, F. Superior 5' homogeneity of RNA from ATP-initiated transcription under the T7 phi 2.5 promoter. Nucleic Acids Res. 2004, 32, 2-5. [CrossRef] [PubMed]

77. Dunn, J.J.; Studier, F.W. Complete nucleotide sequence of bacteriophage T7 DNA and the locations of T7 genetic elements. J. Mol. Biol. 1983, 166, 477-535. [CrossRef]

78. Kao, C.; Zheng, M.; Rüdisser, S. A simple and efficient method to reduce nontemplated nucleotide addition at the $3^{\prime}$ terminus of RNAs transcribed by T7 RNA polymerase. RNA 1999, 5, 1268-1272. [CrossRef] [PubMed]

79. Pujari, N.; Saundh, S.L.; Acquah, F.A.; Mooers, B.H.M.; Ferré-D'Amaré, A.R.; Leung, A.K.-W. Engineering Crystal Packing in RNA Structures I: Past and Future Strategies for Engineering RNA Packing in Crystals. Crystals 2021, 11, 952. [CrossRef] [PubMed]

80. Shatkin, A. Capping of eucaryotic mRNAs. Cell 1976, 9, 645-653. [CrossRef]

81. Ramanathan, A.; Robb, G.B.; Chan, S.H. mRNA capping: Biological functions and applications. Nucleic Acids Res. 2016, 44, 7511-7526. [CrossRef]

82. Galloway, A.; Cowling, V.H. mRNA cap regulation in mammalian cell function and fate. Biochim. Biophys. Acta Gene Regul. Mech 2019, 1862, 270-279. [CrossRef]

83. Pardi, N.; Hogan, M.J.; Porter, F.W.; Weissman, D. mRNA vaccines-A new era in vaccinology. Nat. Rev. Drug Discov. 2018, 17, 261-279. [CrossRef]

84. Hodel, A.E.; Gershon, P.D.; Quiocho, F.A. Structural Basis for Sequence-Nonspecific Recognition of 5'-Capped mRNA by a Cap-Modifying Enzyme. Mol. Cell 1998, 1, 443-447. [CrossRef]

85. Shirokikh, N.E.; Preiss, T. Translation initiation by cap-dependent ribosome recruitment: Recent insights and open questions. WIREs RNA 2018, 9, 1-45. [CrossRef] [PubMed]

86. Grudzien-Nogalska, E.; Stepinski, J.; Jemielity, J.; Zuberek, J.; Stolarski, R.; Rhoads, R.E.; Darzynkiewicz, E. Synthesis of AntiReverse Cap Analogs (ARCAs) and their Applications in mRNA Translation and Stability. Methods Enzymol. 2007, 431, 203-227. [CrossRef] [PubMed]

87. Kim, J.; Eygeris, Y.; Gupta, M.; Sahay, G. Self-assembled mRNA vaccines. Adv. Drug Deliv. Rev. 2021, 170, 83-112. [CrossRef] [PubMed]

88. Pelletier, J.; Schmeing, T.M.; Sonenberg, N. The multifaceted eukaryotic cap structure. Wiley Interdiscip. Rev. RNA 2021, 12, e1636. [CrossRef] [PubMed]

89. Ensinger, M.J.; Martin, S.A.; Paoletti, E.; Moss, B. Modification of the $5^{\prime}$-terminus of mRNA by soluble guanylyl and methyl transferases from vaccinia virus. Proc. Natl. Acad. Sci. USA 1975, 72, 2525-2529. [CrossRef]

90. Yisraeli, J.K.; Melton, D.A. Synthesis of long, capped transcripts in Vitro by SP6 and T7 RNA polymerases. Methods Enzymol. 1989, $180,42-50$

91. Nielsen, D.A.; Shapiro, D.J. Preparation of capped RNA transcripts using T7 RNA polymerase. Nucleic Acids Res. 1986, 14, 5936. [CrossRef]

92. Konarska, M.M.; Padgett, R.A.; Sharp, P.A. Recognition of cap structure in splicing in vitro of mRNA precursors. Cell 1984, 38, 731-736. [CrossRef]

93. Jemielity, J.; Fowler, T.; Zuberek, J.; Stepinski, J.; Lewdorowicz, M.; Niedzwiecka, A.; Stolarski, R.; Darzynkiewicz, E.; Rhoads, R.E. Novel "anti-reverse" cap analogs with superior translational properties. RNA 2003, 9, 1108-1122. [CrossRef]

94. Stepinski, J.; Waddell, C.; Stolarski, R.; Darzynkiewicz, E.; Rhoads, R.E. Synthesis and properties of mRNAs containing the novel “ anti-reverse" cap analogs. RNA 2001, 7, 1486-1495. [CrossRef] [PubMed]

95. Sikorski, P.J.; Warminski, M.; Kubacka, D.; Ratajczak, T.; Nowis, D.; Kowalska, J.; Jemielity, J. The identity and methylation status of the first transcribed nucleotide in eukaryotic mRNA $5^{\prime}$ cap modulates protein expression in living cells. Nucleic Acids Res. 2020, 48, 1607-1626. [CrossRef] [PubMed]

96. Henderson, J.M.; Ujita, A.; Hill, E.; Yousif-Rosales, S.; Smith, C.; Ko, N.; McReynolds, T.; Cabral, C.R.; Escamilla-Powers, J.R.; Houston, M.E. Cap 1 Messenger RNA Synthesis with Co-transcriptional CleanCap ${ }^{\circledR}$ Analog by In Vitro Transcription. Curr. Protoc. 2021, 1, 1-17. [CrossRef] [PubMed]

97. Thillier, Y.; Decroly, E.; Morvan, F.; Canard, B.; Vasseur, J.-J.; Debart, F. Synthesis of 5' cap-0 and cap-1 RNAs using solid-phase chemistry coupled with enzymatic methylation by human (guanine- N 7)-methyl transferase. RNA 2012, 18, 856-868. [CrossRef] [PubMed]

98. Jemielity, J.; Heinonen, P.; Lönnberg, H.; Darzynkiewicz, E. A novel approach to solid phase chemical synthesis of Oligonucleotides mRNA CAP analogs. Nucleosides Nucleotides Nucleic Acids 2005, 24, 601-605. [CrossRef]

99. Kadokura, M.; Wada, T.; Seio, K.; Moriguchi, T.; Huber, J.; Lührmann, R.; Sekine, M. Solid-phase synthesis of a $5^{\prime}$-terminal TMG-capped trinucleotide block of U1 snRNA. Tetrahedron Lett. 2001, 42, 8853-8856. [CrossRef] 
100. Tanner, N.K. Ribozymes: The characteristics and properties of catalytic RNAs. FEMS Microbiol. Rev. 1999, 23, 257-275. [CrossRef]

101. Weinberg, C.E.; Weinberg, Z.; Hammann, C. Novel ribozymes: Discovery, catalytic mechanisms, and the quest to understand biological function. Nucleic Acids Res. 2019, 47, 9480-9494. [CrossRef]

102. Doherty, E.A.; Doudna, J.A. Ribozyme Structures and Mechanisms. Annu. Rev. Biochem. 2000, 69, 597-615. [CrossRef]

103. Müller, S.; Appel, B.; Balke, D.; Hieronymus, R.; Nübel, C. Thirty-five years of research into ribozymes and nucleic acid catalysis: Where do we stand today? F1000Research 2016, 5, 1511. [CrossRef]

104. Maurel, M.-C.; Leclerc, F.; Hervé, G. Ribozyme Chemistry: To Be or Not To Be under High Pressure. Chem. Rev. Am. Chem. Soc. 2020, 120, 4898-4918. [CrossRef] [PubMed]

105. Ferré-D'Amaré, A.R. The glmSribozyme: Use of a small molecule coenzyme by a gene-regulatory RNA. Q. Rev. Biophys. 2010, 43, 423-447. [CrossRef] [PubMed]

106. Kieft, J.S.; Batey, R.T. A general method for rapid and nondenaturing purification of RNAs. RNA 2004, 10, 988-995. [CrossRef] [PubMed]

107. Salvail-Lacoste, A.; Di Tomasso, G.; Piette, B.L.; Legault, P. Affinity purification of T7 RNA transcripts with homogeneous ends using ARiBo and CRISPR tags. RNA 2013, 19, 1003-1014. [CrossRef] [PubMed]

108. Schürer, H.; Lang, K.; Schuster, J.; Mörl, M. A universal method to produce in vitro transcripts with homogeneous $3^{\prime}$ ends. Nucleic Acids Res. 2002, 30, e56. [CrossRef] [PubMed]

109. Morl, M.; Hartmann, R.K. Production of RNAs with Homogeneous $5^{\prime}$ and $3^{\prime}$ Ends. In Handbook of RNA Biochemistry; Wiley-VCH: Weinheim, Germany, 2008; pp. 22-35, ISBN 3527308261.

110. Ferré-D'Amaré, A.R.; Doudna, J.A. Use of cis- and trans-ribozymes to remove $5^{\prime}$ and $3^{\prime}$ heterogeneities from milligrams of in vitro transcribed RNA. Nucleic Acids Res. 1996, 24, 977-978. [CrossRef]

111. Wichlacz, A.; Łegiewicz, M.; Ciesiołka, J. Generating in vitro transcripts with homogenous $3^{\prime}$ ends using trans-acting antigenomic delta ribozyme. Nucleic Acids Res. 2004, 32, e39. [CrossRef] [PubMed]

112. De La Peña, M.; García-Robles, I.; Cervera, A. The hammerhead Ribozyme: A long history for a short RNA. Molecules 2017, $22,78$. [CrossRef]

113. De La Peña, M.; Dufour, D.; Gallego, J. Three-way RNA junctions with remote tertiary contacts: A recurrent and highly versatile fold. RNA 2009, 15, 1949-1964. [CrossRef]

114. Martick, M.; Scott, W.G. Tertiary Contacts Distant from the Active Site Prime a Ribozyme for Catalysis. Cell 2006, 126, 309-320. [CrossRef]

115. Amarzguioui, M.; Prydz, H. Hammerhead ribozyme design and application. Cell. Mol. Life Sci. 1998, 54, 1175-1202. [CrossRef] [PubMed]

116. Scott, W.G.; Horan, L.H.; Martick, M. The Hammerhead Ribozyme: Structure, Catalysis, and Gene Regulation, 1st ed.; Elsevier: Amsterdam, The Netherlands, 2013; Volume 120, ISBN 9780123812865.

117. Oubridge, C.; Kuglstatter, A.; Jovine, L.; Nagai, K. Crystal structure of SRP19 in complex with the S domain of SRP RNA and its implication for the assembly of the signal recognition particle. Mol. Cell 2002, 9, 1251-1261. [CrossRef]

118. Jovine, L.; Hainzl, T.; Oubridge, C.; Scott, W.G.; Li, J.; Sixma, T.K.; Wonacott, A.; Skarzynski, T.; Nagai, K. Crystal structure of the Ffh and EF-G binding sites in the conserved domain IV of Escherichia coli 4.5S RNA. Structure 2000, 8, 527-540. [CrossRef]

119. Battaglia, R.A.; Grigg, J.C.; Ke, A. Structural basis for tRNA decoding and aminoacylation sensing by T-box riboregulators. Nat. Struct. Mol. Biol. 2019, 26, 1106-1113. [CrossRef] [PubMed]

120. Walter, N.G.; Burke, J.M. The hairpin ribozyme: Structure, assembly and catalysis. Curr. Opin. Chem. Biol. 1998, 2, 24-30. [CrossRef]

121. Rupert, P.B.; Ferré-D'Amaré, A.R. Crystal structure of a hairpin ribozyme-inhibitor complex with implications for catalysis. Nature 2001, 410, 780-786. [CrossRef] [PubMed]

122. Webb, C.-H.T.; Lupták, A. HDV-like self-cleaving ribozymes. RNA Biol. 2011, 8, 719-727. [CrossRef]

123. Tanner, N.K.; Schaff, S.; Thill, G.; Petit-Koskas, E.; Crain-Denoyelle, A.M.; Westhof, E. A three-dimensional model of hepatitis delta virus ribozyme based on biochemical and mutational analyses. Curr. Biol. 1994, 4, 488-498. [CrossRef]

124. Chen, J.-H.; Yajima, R.; Chadalavada, D.M.; Chase, E.; Bevilacqua, P.C.; Golden, B.L. A 1.9 A Crystal Structure of the HDV Ribozyme Precleavage Suggests both Lewis Acid and General Acid Mechanisms Contribute to Phosphodiester Cleavage. Biochemistry 2010, 49, 6508-6518. [CrossRef]

125. Suh, Y.A.; Kumar, P.K.R.; Taira, K.; Nishikawa, S. Self-cleavage activity of the genomic HDV ribozyme in the presence of various divalent metal ions. Nucleic Acids Res. 1993, 21, 3277-3280. [CrossRef]

126. Doudna, J.A. Preparation of homogeneous ribozyme RNA for crystallization. Methods Mol. Biol. 1997, 74, 365-370. [CrossRef] [PubMed]

127. Peselis, A.; Gao, A.; Serganov, A. Preparation and crystallization of riboswitches. Methods Mol. Biol. 2016, 1320, 21-36. [CrossRef] [PubMed]

128. Steckelberg, A.L.; Akiyama, B.M.; Costantino, D.A.; Sit, T.L.; Nix, J.C.; Kieft, J.S. A folded viral noncoding RNA blocks host cell exoribonucleases through a conformationally dynamic RNA structure. Proc. Natl. Acad. Sci. USA 2018, 115, 6404-6409. [CrossRef] [PubMed] 
129. Chen, H.; Egger, M.; Xu, X.; Flemmich, L.; Krasheninina, O.; Sun, A.; Micura, R.; Ren, A. Structural distinctions between NAD+riboswitch domains 1 and 2 determine differential folding and ligand binding. Nucleic Acids Res. 2020, 48, 12394-12406. [CrossRef]

130. Binas, O.; Tants, J.N.; Peter, S.A.; Janowski, R.; Davydova, E.; Braun, J.; Niessing, D.; Schwalbe, H.; Weigand, J.E.; Schlundt, A. Structural basis for the recognition of transiently structured AU-rich elements by Roquin. Nucleic Acids Res. 2020, 48, 7385-7403. [CrossRef]

131. Saville, B.J.; Collins, R.A. A site-specific self-cleavage reaction performed by a novel RNA in neurospora mitochondria. Cell 1990, 61, 685-696. [CrossRef]

132. Suslov, N.B.; Dasgupta, S.; Huang, H.; Fuller, J.R.; Lilley, D.M.J.; Rice, P.A.; Piccirilli, J.A. Crystal Structure of the vs. ribozyme. Nat. Chem. Biol. 2015, 11, 840-846. [CrossRef]

133. Guo, H.C.T.; Collins, R.A. Efficient trans-cleavage of a stem-loop RNA substrate by a ribozyme derived from Neurospora vs. RNA. EMBO J. 1995, 14, 368-376. [CrossRef]

134. Duss, O.; Maris, C.; von Schroetter, C.; Allain, F.H.T. A fast, efficient and sequence-independent method for flexible multiple segmental isotope labeling of RNA using ribozyme and RNase H cleavage. Nucleic Acids Res. 2010, 38, e188. [CrossRef]

135. Barrick, J.E.; Corbino, K.A.; Winkler, W.C.; Nahvi, A.; Mandal, M.; Collins, J.; Lee, M.; Roth, A.; Sudarsan, N.; Jona, I.; et al. New RNA motifs suggest an expanded scope for riboswitches in bacterial genetic control. Proc. Natl. Acad. Sci. USA 2004, 101, 6421-6426. [CrossRef]

136. Klein, D.J.; Ferré-D'Amaré, A.R. Structural basis of glmS ribozyme activation by glucosamine-6-phosphate. Science 2006, 313, 1752-1756. [CrossRef]

137. Chapman, E.G.; Costantino, D.A.; Rabe, J.L.; Moon, S.L.; Wilusz, J.; Nix, J.C.; Kieft, J.S. The structural basis of pathogenic subgenomic flavivirus RNA (sfRNA) production. Science 2014, 344, 307-310. [CrossRef] [PubMed]

138. Kao, C.; Rüdisser, S.; Zheng, M. A simple and efficient method to transcribe RNAs with reduced $3^{\prime}$ heterogeneity. Methods 2001, 23, 201-205. [CrossRef] [PubMed]

139. Helmling, C.; Keyhani, S.; Sochor, F.; Fürtig, B.; Hengesbach, M.; Schwalbe, H. Rapid NMR screening of RNA secondary structure and binding. J. Biomol. NMR 2015, 63, 67-76. [CrossRef]

140. Karlsson, H.; Baronti, L.; Petzold, K. A robust and versatile method for production and purification of large-scale RNA samples for structural biology. RNA 2020, 26, 1023-1037. [CrossRef]

141. Keane, S.C.; Van, V.; Frank, H.M.; Sciandra, C.A.; McCowin, S.; Santos, J.; Heng, X.; Summers, M.F. NMR detection of intermolecular interaction sites in the dimeric 5'-leader of the HIV-1 genome. Proc. Natl. Acad. Sci. USA 2016, 113, 13033-13038. [CrossRef]

142. Kanwal, F.; Chen, T.; Zhang, Y.; Simair, A.; Rujie, C.; Sadaf Zaidi, N.U.S.; Guo, X.; Wei, X.; Siegel, G.; Lu, C. Large-Scale in Vitro Transcription, RNA Purification and Chemical Probing Analysis. Cell. Physiol. Biochem. 2018, 48, 1915-1927. [CrossRef]

143. Zhang, H.; Keane, S.C. Advances that facilitate the study of large RNA structure and dynamics by nuclear magnetic resonance spectroscopy. Wiley Interdiscip. Rev. RNA 2019, 10, 1-15. [CrossRef] [PubMed] 